\title{
Prediction of the Erosiveness of Puerto Rican Soils on a Basis of the Percentage of Particles of Silt and Clay When Aggregated
}

\author{
M. A. Lugo-López ${ }^{1}$
}

\section{INTRODUCTION}

The development of adequate indices for measuring the degree of erodibility of soils is of paramount importance. The lack of published information on the erodibility of tropical soils is particularly noticeable.

This paper reports on an attempt to simplify the procedures to evaluate the relative erosiveness of these soils. The work herein reported comprises an approach to erodibility in terms of a single soil property, i.e., the percentage of silt and clay aggregated. This property may be easily assessed in the laboratory.

\section{EARLIER WORK}

In 1950, Bonnet and Lugo-López (2) 2 published a paper on the relative erosiveness of Puerto Rican soils. They applied the criteria proposed by Middleton (4) to evaluate the erosiveness of 15 typical soils of various areas in Puerto Rico. Middleton (4) once proposed the socalled dispersion ratio which is a function of soil aggregation, and also proposed the colloidmoisture equivalent ratio, a function of the ease of percolation and the absorptive power of the soil. He then combined these ratios into a single one which he called the "erosion ratio".

Bonnet and Lugo-López (2) classified the soils used in their early work into lateritic, red and yellow podzolic, gray-brown podzolic, lithosols, reddish prairie, and alluvials. An upland Catalina clay profile with dispersion ratios of 12-20, colloid-moisture equivalent ratios of $0.97-2.26$, and erosion ratios of 6-14, lost from 5.3 to 7.1 tons of soil per inch of run-off per acre per year, when in fallow or desurfaced, respectively. However, when this soil was planted to sugarcane the losses were reduced to 1.5 and, 0.13 tons of soil per inch of run-off when the trash was burned or kept as a mulch, respectively. This lateritic Catalina clay was classed as a nonerosive soil. The red and yellow podzolic Fajardo clay loam is as nonerosive as the lateritic Catalina clay. The upland lateritic Alonso and Río Piedras soils, and some areas of the lateritic Cialitos soils are more erosive than the Catalina clay. The level alluvial Coloso soil is also more erosive.

1 Soil Scientist, Agricultural Experiment Station, Mayagüez Campus, University of Puerto Rico, Río Piedras, P.R.

2 Italic numbers in parentheses refer to Literature Cited, p. 190. 
The gray-brown podzolics or lithosols, represented by the Cayauag sandy loam and Pandura sandy clay loam with ranges of disperison ratios of 27 to 87 , colloid-moisture equivalent ratios of 0.41 to 0.60 and erosion ratios of 67 to 177, are highly erosive soils. The Múcara clay loam of the same group, with ranges of dispersion ratios of 21 to 63, colloid-moisture equivalent ratios of 0.53 to 0.65 , and erosion ratios of 33 to 97 is also a highly erosive soil. The reddish prairie Machete loam, an alluvial soil in the semiarid area, is also an erosive soil.

\section{ANALYTICAL WORK AND CALCULATIONS}

Moisture-equivalent values were determined by using a special centrifuge. Colloids were determined by the pipette method, considering the colloids as the clay fraction below $0.002 \mathrm{~mm}$. in size. Aggregate analysis and total silt and clay were run with a Kopecky type of elutriator (1), consisting of three vessels with internal diameters of 30,56 , and $78 \mathrm{~mm}$. The first vessel retained the particles with a diameter range of 2.0 to $0.1 \mathrm{~mm}$., the second one with 0.1 to $0.05 \mathrm{~mm}$; and the third one with 0.05 to $0.02 \mathrm{~mm}$. An aggregate analysis was run on each sample, and a second one was run after destroying the organic matter with hydrogen peroxide and dispersing the colloids with sodium silicate. The silt and clay aggregated (B), the dispersion ratio, the colloid-moisture equivalent ratio and the erosion ratio $(4,5,6)$ were calculated as follows:

$$
\text { Dispersion ratio }=\frac{\text { percent silt and clay aggregated }}{\text { total silt and clay }} \times 100
$$

Percent silt and clay aggregated $=\frac{x-y}{100-y} \times 100$,

where $x=$ all particles greater than $0.05 \mathrm{~mm}$. in the soil in its natural occurrence, without dispersion, and $y=$ all particles greater than 0.05 $\mathrm{mm}$. in the soil after the organic matter is destroyed and the soil dispersed. Total silt and clay $=$ all particles less than $0.05 \mathrm{~mm}$. after dispersion.

Colloid-moisture equivalent ratio $=\frac{\text { percent particles less than } 0.002 \mathrm{~mm}}{\text { moisture equivalent }}$

$$
\text { Erosion ratio }=\frac{\text { Dispersion ratio }}{\text { Colloid-moisture equivalent ratio }}
$$

The original data were published elsewhere (P) as previously mentioned. For the study herein reported the correlation between the erosion ratio and the percentage of silt and clay aggregated was determined. The straightline relation between these two indices is: 


$$
\begin{aligned}
& \text { Erosion ratio }=125.47-1.42 X, \text { where } \\
& X=\text { percentage of silt and clay aggregated }
\end{aligned}
$$

\section{DISCUSSION}

The value of the correlation coefficient between these two indices was found to be 0.79 . It is therefore suggested that the percentage of silt and clay aggregated be considered as an index of the erodibility of the soil.

In view of the rather simple laboratory procedures necessary to evaluate this index, and the relatively high correlation of the index with the more widely used but more complex erosion ratio, the use of this index should permit a wider evaluation of the erodibility of soils by simplifying the procedures now used.

The statistical work reveals that, as the percentage of silt and clay ag-. gregated increases, the erosion ratio decreases. This is to be expected since the percentage of silt and clay aggregated enters into the calculation of the despersion ratio which, in turn, when divided by the colloid moistureequivalent ratio, gives the erosion ratio as proposed by Middleton. The percentage of silt and clay aggregated can be obtained as outlined in the preceding procedure by quite simple laboratory work where the percentage of particles larger than $0.05 \mathrm{~mm}$. is obtained in a soil sample prior to the destruction of organic matter and dispersion, and also subsequent to organic-matter destruction with hydrogen peroxide, and dispersion with sodium silicate. The pipette method is rather accurate in this respect, but any other suitable method can be used. The subsequent calculations are very simple.

There is need for more adequate indices for measuring the degree of erodibility of tropical soils. There is particular need for indices which will allow the prediction of erodibility with a higher degree of precision, but still using simple, quantified soil properties as a basis.

\section{SUMMARY}

An approach is suggested in this paper that permits an estimation of the erodibility of soils on a basis of the percentage of particles of silt and clay aggregated. A correlation coefficient of 0.79 was obtained between the percentage of silt and clay aggregated and the erosion ratio. The erosion ratio is a rather valuable soil index, but is complex, and the determination and calculations for each of its components are rather laborious. On the other hand, the laboratory determination of precisely the percentage of silt and clay particles aggregated can be made easy and simple. The calculations are also easy. 
The percentage of silt and clay aggregated is therefore a convenient index to use in assessing the erodibility of a soil. If desired, the corresponding value of the erosion ratio may be estimated with a fair degree of precision from the percentage of silt and clay aggregated.

\section{RESUMEN}

En este trabajo se sugiere un índice para estimar la erosionabilidad de los suelos basándose en el porcentaje de partículas de limo y arcilla agregados. El coeficiente de correlación entre este índice y la tasa de erosión de Middleton es 0.79. La tasa de erosión es una de las medidas más importantes de los suelos, pero por su complejidad, tanto la determinación de cada uno de sus componentes así como los cálculos que hay que hacer, pueden ser bastente laboriosos. En cambio, la determinación del porcentaje de partículas de limo y arcilla agregadas es bastante fácil y relativamente rápida bajo condiciones de laboratorio. Los cálculos también son fáciles.

Por los tanto, el uso del porcentaje de limo y arcilla agregados es un índice útil para evaluar la erosionabilidad de los suelos. Si se desea obtener el valor de la tasa de erosión, éste puede estimarse con relativa precisión si se utiliza el índice propuesto.

\section{LITERATURE CITED}

1. Baver, L. D. and Rhoades, H. F., Aggregate analysis as an aid in the study of soil structure relationships, J. Amer. Soc. Agron. 24: 920-30, 1932.

2. Bonnet, J. A. and Lugo-López, M. A., Relative erosiveness of Puerto Rico soils, J. Agr. Univ. P. R. S4 (3): 294-307, 1950.

3. Lutz, J. F., The physico-chemical properties of soils affecting soil erosion, Res. Bul. 212, Mo. Agr. Expt. Sta., 1934.

4. Middleton, H. E., Properties of soils which influence soil erosion, USDA Tech. Bul. 178, 1930.

5. Middleton, H. E., Slater, C. S., and Byers, H. G., Physical and chemical characteristics of the soils from the erosion experiment stations, USDA Tech. Bul. 316, 1932.

6. Middleton, H. E., Slater, C. S., and Byers, H. G., Physical and ehemical characteristics of the soils from the erosion experiment stations. Second report, USDA Tech. Bul. 430, 1934. 